Original article (Orijinal araştırma)

\title{
Comparison of hermaphrodites of hybrid Heterorhabditis bacteriophora Poinar, 1976 (Rhabditida: Heterorhabditidae) HBH strain and its parents on reproduction capacity ${ }^{\mathbf{1}}$
}

\author{
Hibrit Heterorhabditis bacteriophora Poinar, 1976 (Rhabditida: Heterorhabditidae) HBH \\ ırkı ve ebeveynlerinin hermafroditlerinin üreme kapasitelerinin karşılaştııılması \\ Tufan Can ULU2*iD \\ Şeyma Hümeyra ÇAKIR ${ }^{3}$ \\ Elif Özge DÜZENLíi \\ İsmail Alper SUSURLUK ${ }^{3}$
}

\begin{abstract}
Entomopathogenic nematodes (EPNs) are microscopic roundworms used in biocontrol. EPNs are obligate insect parasites, they live in soil, and they are especially effective against soilborne insects. They are a good alternative to chemical pesticides thanks to their advantages, such as prolonged longevity, broad host range and mass production suitability. However, EPNs cannot compete with chemical pesticides due to high production costs and short shelf life. The aim of this study was to determine the reproduction capacity of the Turkish hybrid Heterorhabditis bacteriophora Poinar, 1976 (Rhabditida: Heterorhabditidae) HBH strain and then compare it with its parents to improve its liquid culture yield. In this way, it is aimed to reveal the effects behind the high reproduction potential of the hybrid $\mathrm{HBH}$ strain. All experiments were performed at Bursa Uludağ University, Faculty of Agriculture, Department of Plant Protection, in 2020. All cadavers were periodically dissected, hermaphrodites were counted and their body lengths were measured. Compared to its parents, the hybrid HBH strain had greater hermaphrodite counts, with mean 66 individuals within 12 days, and hermaphrodite body length, with mean $3.88 \mathrm{~mm}$. The results obtained from this study should provide information for commercial EPN production development.
\end{abstract}

Keywords: Body length, hermaphrodite, Heterorhabditis bacteriophora, in vitro, reproduction capacity

\section{Öz}

Entomopatojen nematodlar (EPN) biyolojik mücadelede kullanılan mikroskobik ölçülerdeki yuvarlak solucanlardır. EPN'ler zorunlu böcek parazitleri olup, toprak altında yaşamakta ve toprak kökenli böceklere karşı etkili olmaktadırlar. Uygulamalarının kolay olması, uzun sürekli etkinliği, geniş konukçu aralığı ve kitle üretimi yapılabilmesi gibi avantajları sayesinde kimyasal ilaçlara iyi bir alternatif olmaktadırlar. Bununla beraber, yüksek üretim maliyetleri ve kısa raf ömrü nedeniyle EPN'ler kimyasal ilaçlar ile rekabet edememektedir. Bu çalışma, sıvı kültürdeki üretim verimini artırmak amacıyla Türk hibriti Heterorhabditis bacteriophora Poinar, 1976 (Rhabditida: Heterorhabditidae) $\mathrm{HBH}$ ırkının üreme kapasitesini belirlemek ve ebeveynleri ile karşılaştırmak amacıyla yapılmıştır. Bu sayede hibrit HBH ırkının yüksek üreme potansiyelinin arkasında yatan etkilerin ortaya çıkarılması hedeflenmiştir. Tüm denemeler Bursa Uludağ Üniversitesi Ziraat Fakültesi Bitki Koruma Bölümü'nde 2020 yılında gerçekleştirilmiştir. Bütün kadavralar periyodik olarak disekte edilmiş, hermafroditler sayılmış ve vücut uzunlukları ölçülmüştür. Ebeveynleri ile karşılaştırıldığında, hibrit HBH ırkı, 12 günde ortalama 66 hermafrodit birey ile hermafrodit sayısında ve ortalama 3.88 $\mathrm{mm}$ ile hermafrodit vücut uzunluğu açısından daha yüksek değerlere sahip olmuştur. Bu çalışma ile elde edilen sonuçlar, ticari EPN üretim çalışmalarına bilgi sağlayacaktır.

Anahtar sözcükler: Vücut uzunluğu, hermafrodit, Heterorhabditis bacteriophora, in vitro, üreme kapasitesi

\footnotetext{
1 This study was financially supported by the TUBITAK (The Scientific and Technological Research Council of Turkey), Project number: TOVAG 2190370.

2 Bilecik Şeyh Edebali University, Faculty of Agriculture and Natural Sciences, Department of Plant Protection, 11230, Bilecik, Turkey

${ }^{3}$ Bursa Uludağ University, Faculty of Agriculture, Department of Plant Protection, 16059, Bursa, Turkey

* Corresponding author (Sorumlu yazar) e-mail: tufan.ulu@bilecik.edu.tr

Received (Alınış): 13.01.2021 Accepted (Kabul ediliş): 03.04.2021 


\section{Introduction}

Many insect pathogens occur in the phylum Nematoda, but species within the families Steinernematidae and Heterorhabditidae have gained significant importance as biocontrol agents in plant protection. Entomopathogenic nematodes (EPN) are important biocontrol agents, and they can be especially used to control soil-dwelling insect pests (Lacey \& Georgis, 2012). They have a high potential on a broad host range of insects thanks to their host-seeking ability (Divya \& Sankar, 2009; Lacey \& Georgis, 2012). These nematodes are associated with bacteria in the genus Photorhabdus Boemare et al., 1993 (Enterobacteriales: Enterobacteriaceae) for Heterorhabditis Poinar, 1976 (Rhabditida: Heterorhabditidae) and Xenorhabdus Thomas \& Poinar, 1979 (Enterobacteriales: Enterobacteriaceae) for Steinernema Travassos, 1927 (Rhabditida: Steinernematidae) (Boemare et al., 1996). The life cycles of EPNs are quite similar. The only stage living outside the host is the infective juveniles (IJs). The IJs carry cells of the bacterial symbiont in their intestine. When the IJs find a susceptible host, they invade and penetrate the host's hemocoel through natural openings (i.e., anus, mouth or spiracles). The IJs then release the symbiotic bacterium that kills the host within $48 \mathrm{~h}$ by septicemia (Kaya \& Gaugler, 1993). The bacterium produces antibiotics to prevent other microorganisms from colonizing the cadaver (Bode, 2009; Sajnaga \& Kazimierczak, 2020). Besides serving as a food source for the nematode, the bacterium also provides proper nutrients for nematode development. After 2-3 weeks, the food resource depletes in the cadaver, and IJs disperse through the soil to find new hosts.

EPNs can be applied with standard spray equipment used for pesticides, they can resist shear stress, they can be applied simultaneously with many pesticides, and they can be mass-produced to manage with a broad host range (Wright et al., 2005; Garcia-del-Pino et al., 2013; van Niekerk \& Malan, 2014; Sabino et al., 2019). Although they have many advantages, high production costs and limited shelf life are still significant obstacles to the large-scale application (Grewal, 2000; Perry et al., 2012). Therefore, there are many studies focused on reducing production costs. Previous research has established that, many local strains of EPNs have better infectivity and reproduction capacity than commercial ones (Malan \& Moore, 2016; De Waal et al., 2018; James et al., 2018; Mokrini et al., 2020), and can be used to increase mass production yield and lower expenses. Another way to improve beneficial traits of EPNs is genetic selection and hybridization. Over the past two decades, considerable research has focused on improving some beneficial traits by selection (Johnigk et al., 2002; Ehlers et al., 2005; Mukuka et al., 2010; Salame et al., 2010; Anbesse et al., 2013).

Between 2010 and 2013, several hybrid Heterorhabditis bacteriophora Poinar, 1976 (Rhabditida: Heterorhabditidae) strains were obtained from hybridization of Turkish isolates of $H$. bacteriophora. Among these strains, $\mathrm{HBH}$ had superior genetic traits, such as high reproduction capacity, high virulence, high resistance to stress conditions, and prolonged longevity (Susurluk et al., 2013). EPNs have been registered in Turkey, and they have an increasing market share. Since Turkey does not have any commercial EPN strain and liquid production technology, imported commercial EPN products are used. The HBH hybrid strain has superior features, and it has the potential to be a commercial strain. Consequently, it is important to understand the reason of the hybrid strain's characteristics to optimize and improve mass production, longevity and stress tolerance.

This study aimed to compare the reproduction capacity and hermaphrodite length of $\mathrm{HBH}$ hybrid strain with its parents. There may be a positive correlation between body length and ovary size, which can also mean longer individuals have higher reproductive potential. The study also collected data to determine the reason for its higher reproduction capacity. It is hoped that the results of this study will contribute information for future in vitro liquid culture experiments. 


\section{Materials and Methods}

This study was conducted at Bursa Uludağ University, Department of Plant Protection, Nematology Laboratory, in 2020.

\section{EPN strains and Galleria mellonella larvae}

Two parent strains, H. bacteriophora HB4 and HB1138, and one hybrid HBH strain patented by Susurluk (TPMK Patent No: TR 201306141 B) were used. Parent strains were isolated from two different regions of Turkey. The hybrid strain was obtained from hybridization of those parent strains. $H$. bacteriophora is one of Turkey's most abundant EPN species, and our hybrid strain has superior genetic traits (Susurluk et al., 2001, 2013; Kongu \& Susurluk, 2014). The last instar of Galleria mellonella L., 1758 (Lepidoptera: Pyralidae) larvae are used for the production of EPNs. Larvae are reared with a modified diet consisting of $200 \mathrm{~g}$ bran, $150 \mathrm{~g}$ maize flour, $100 \mathrm{~g}$ soy flour, $100 \mathrm{~g}$ milk powder, $50 \mathrm{~g}$ yeast, $200 \mathrm{~g}$ glycerin and $200 \mathrm{~g}$ honey. All larvae were kept in glass jars and incubated around $30-32^{\circ} \mathrm{C}$.

\section{Experimental design and inoculation of the strains}

For determining reproduction capacity, 30 last instar larvae were inoculated with EPNs and divided into five replicates, consisting six larvae per Petri dish. Prior to inoculation, $10 \mu \mathrm{l}$ samples were taken from EPN cultures and counted under a microscope. Inoculation dose were adjusted to $100 \mathrm{IJs} / \mathrm{larva}$, and a total of 600 IJs were applied per Petri dish. After inoculation, Petri dishes were sealed with Parafilm and incubated at $24^{\circ} \mathrm{C}$. Cadavers were dissected on $4,6,8,10$ and 12 days after inoculation (DAI). For dissection, dead larvae were transferred to a bigger Petri dish containing a thin layer of Ringer's solution. All cadavers were dissected with a needle and all extracted nematodes transferred to a fresh Ringer's solution.

\section{Reproduction capacity criteria}

Hermaphrodites of Heterorhabditis spp. are positively correlated with the offspring and reproduction capacity. Namely, higher numbers of hermaphrodites are the sign of higher yield. Moreover, the longer body length of the hermaphrodites leads to longer ovaries, which also results in more reproduction yield. Thus, after each dissection process, hermaphrodites of each strain were counted under stereomicroscope, and body lengths of the individuals were measured using Leica Application Suite 3.2 software (Leica, Weztlar, Germany). Body lengths of 15 hermaphrodites were measured for each strain.

\section{Statistical analyses}

Statistical analysis for both the reproduction capacity and hermaphrodite body measurements was performed using JMP 7 software (SAS Institute, Cary, NC, USA). One-way ANOVA analysis was performed on data obtained from experiments.

\section{Results and Discussion}

\section{Reproduction capacity}

Reproduction capacity was determined based on periodic counts of hermaphrodites. For all strains, the first hermaphrodites were observed $6 \mathrm{DAl}$. Among the three strains, the hybrid $\mathrm{HBH}$ strain had the best results for overall hermaphrodite number over the 12 days $\left(F_{2,15}=23.8, p<0.001\right)$. The hybrid strain had almost two times more hermaphrodites than its parent HB1138. As evident in Figure 1, reproduction dynamics of the same species can differ between strains. HB4 strain reached its peak total hermaphrodite number $8 \mathrm{DAl}$, while it was $10 \mathrm{DAl}$ for $\mathrm{HBH}$ and $12 \mathrm{DAl}$ for HB1138 (Figure 1). There was clear decrease of the hermaphrodites in all strains following their peak day, which was related to their second or third generation in the cadaver. 


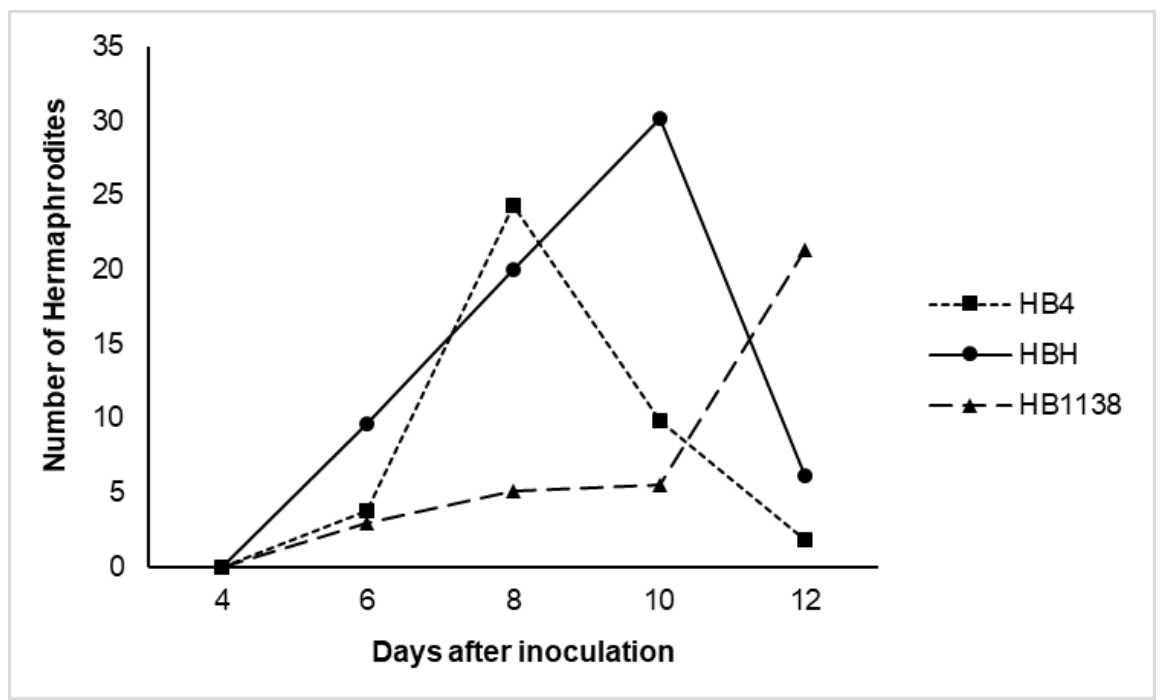

Figure 1. Daily changes in the number of hermaphrodites.

\section{Body length measurement}

The reproduction capacity of the strains is also related to hermaphrodite body length. The longer body length leads to a longer ovary, which increases the number of eggs. The HB1138 had the shortest hermaphrodite body length $(2.07 \pm 0.21 \mathrm{~mm}$, mean $\pm \mathrm{SD}, \mathrm{n}=15)$, while HB4 and HBH lengths were closer (3.61 \pm 0.26 and $3.88 \pm 0.29 \mathrm{~mm}$, respectively), with $\mathrm{HBH}$ being the longest $\left(F_{2,15}=204, p<0.001\right)$.

Entomopathogenic nematodes are useful for biological control of insect pests. Management of soildwelling insects still a significant problem due to the low activity of pesticides into soil. Therefore, EPNs are a good alternative to chemicals. In addition, their application is relatively easy, they have a broad host range and they are a safe solution compared to chemicals. However, even though they have many advantages, they still need more development to become a commercial substitute for chemical pesticides. EPNs have high mass production costs, expensive commercial products and short shelf life. For this reason, many studies have been conducted over several decades to reduce production costs, directly or indirectly. Optimization of in vivo and in vivo culture is one of the most studied topics (van Zyl \& Malan, 2014; Ferreira et al., 2016; Ulu \& Susurluk, 2018; Dunn et al., 2020).

Mass production of EPNs in liquid culture is the most common and feasible way for commercial production (Dunn et al., 2021). There are many commercial EPN strains with optimized liquid culture parameters. However, new endemic species or strains, which may have positive genetic traits, are important for mass production yield, effectiveness, host range, resistance to stress factors and other factors. Thus, considerable research has attempted to optimize in vitro liquid culture production of local species or strains (Upadhyay, 2015; Ramakuwela et al., 2016; Dunn et al., 2020). High liquid culture yield, high effectiveness or longer shelf life lowers commercial product expenses indirectly and contributes EPNs to compete with chemicals (Grewal, 2000; Shapiro-Ilan et al., 2012; Devi \& George, 2018).

Another way to improve EPNs is genetic selection or hybridization. With these tools, it is possible to obtain superior strains, which have the potential to improve on current strains and to become a commercial product. There are many studies focused on the genetic selection of EPNs. The main idea of these studies is to improve the resistance of EPNs to several stress factors, longevity or effectiveness (Shapiro-Ilan et al., 1997; Ehlers et al., 2005; Mukuka et al., 2010; Nimkingrat et al., 2013a, b; Santhi et al., 2016). Likewise, in a project between 2010 and 2013, many hybrid strains of $H$. bacteriophora were obtained from hybridization local Turkish isolates from different regions. Among these hybrid strains, $\mathrm{HBH}$ was the superior strain compared with its parents and other hybrid strains (Susurluk et al., 2013; Kongu \& Susurluk, 2014). To 
understand the reason for the high reproduction capacity of $\mathrm{HBH}$, we counted hermaphrodites of all strains periodically and measured their body length. Although there are very few similar studies, Ferreira et al. (2014) aimed to determine in vitro liquid culture production yield of a South African EPN isolate of Heterorhabditis zealandica (Wouts, 1979) (Rhabditida: Heterorhabditidae). As they mentioned, it is important to monitor the body length of different life stages to improve mass production. Another study by Hirao et al. (2010) aimed to characterize the population development of Steinernema carpocapsae (Weiser, 1955) and Steinernema feltiae (Filipjev, 1934) (Rhabditida: Steinernematidae). They measured the body length of adults and recorded significant differences. They found that even in the same species, the body length of parental adults was doubled in F1 adults.

EPNs have a considerable market share around the world (Glare et al., 2012). However, they still need to overcome some obstacles to increase their market and become preferable. The main problems of EPNs are high mass production expenses, high commercial product cost, and short shelf life (Ali \& Wharton, 2013; Ramakuwela et al., 2016; Kagimu \& Malan, 2019). The present study was designed to determine the reproduction capacity of $\mathrm{HBH}$ hybrid strain and compare it with its parent strains. Reproduction capacity is an important genetic trait for in vitro mass production yield, and it is closely related with hermaphrodites in Heterorhabditis species. The results of this research support the idea that Turkey can have its own hybrid strain with better reproduction capacity. It also provides the first comprehensive assessment of the reproduction capacity of local Turkish strains and a hybrid strain. EPNs are registered in Turkey, and their market share is increasing gradually. Local strains, which are adapted to local conditions, have been shown to have better success. In the future, we think that Turkey should use a local EPN species or strains instead of foreign commercial ones for more effective insect management. We hope that determining the reproduction capacity of this hybrid strains will contribute to future liquid culture optimization studies in Turkey. However, it is recommended that further research should be undertaken on liquid culture methods.

\section{Acknowledgements}

This study was financially supported by the TUBITAK (The Scientific and Technological Research Council of Turkey), Project number: TOVAG 2190370.

\section{References}

Ali, F. \& D. A. Wharton, 2013. Cold tolerance abilities of two entomopathogenic nematodes, Steinernema feltiae and Heterorhabditis bacteriophora. Cryobiology, 66 (1): 24-29.

Anbesse, S., N. H. Sumaya, A. V. Dörfler, O. Strauch \& R. Ehlers, 2013. Stabilization of heat tolerance traits in Heterorhabditis bacteriophora through selective breeding and creation of inbred lines in liquid culture. BioControl, 58 (1): 85-93.

Bode, H. B., 2009. Entomopathogenic bacteria as a source of secondary metabolites. Current Opinion in Chemical Biology, 13 (2): 224-230.

Boemare, N., C. Laumond \& H. Mauleon, 1996. The entomopathogenic nematode-bacterium complex: biology, life cycle and vertebrate safety. Biocontrol Science and Technology, 6 (3): 333-346.

De Waal, J. Y., M. Addison \& A. Malan, 2018. Potential of Heterorhabditis zealandica (Rhabditida: Heterorhabditidae) for the control of codling moth, Cydia pomonella (Lepidoptera: Tortricidae) in semi-field trials under South African conditions. International Journal of Pest Management, 64 (2): 102-109.

Devi, G. \& J. George, 2018. Formulation of Insecticidal Nematode. Annual Research \& Review in Biology, 24 (5): 1-10.

Divya, K. \& M. Sankar, 2009. Entomopathogenic nematodes in pest management. Indian Journal of Science and Technology, 2 (7): 53-60.

Dunn, M. D., P. D. Belur \& A. P. Malan, 2020. In vitro liquid culture and optimization of Steinernema jeffreyense using shake flasks. BioControl, 65 (2): 223-233.

Dunn, M. D., P. D. Belur \& A. P. Malan, 2021. A review of the in vitro liquid mass culture of entomopathogenic nematodes. Biocontrol Science and Technology, 31(1): 1-21. 
Comparison of hermaphrodites of hybrid Heterorhabditis bacteriophora Poinar, 1976 (Rhabditida: Heterorhabditidae) HBH strain and its parents on reproduction capacity

Ehlers, R., J. Oestergaard, S. Hollmer, M. Wingen \& O. Strauch, 2005. Genetic selection for heat tolerance and low temperature activity of the entomopathogenic nematode-bacterium complex Heterorhabditis bacteriophoraPhotorhabdus luminescens. BioControl, 50 (5): 699-716.

Ferreira, T., M. Addison \& A. Malan, 2014. In vitro liquid culture of a South African isolate of Heterorhabditis zealandica for the control of insect pests. African Entomology, 22 (1): 80-92.

Ferreira, T., M. Addison \& A. Malan, 2016. Development and population dynamics of Steinernema yirgalemense (Rhabditida: Steinernematidae) and growth characteristics of its associated Xenorhabdus indica symbiont in liquid culture. Journal of Helminthology, 90 (3): 364-371.

Garcia-del-Pino, F., X. Alabern \& A. Morton, 2013. Efficacy of soil treatments of entomopathogenic nematodes against the larvae, pupae and adults of Tuta absoluta and their interaction with the insecticides used against this insect. BioControl, 58 (6): 723-731.

Glare, T., J. Caradus, W. Gelernter, T. Jackson, N. Keyhani, J. Köhl, P. Marrone, L. Morin \& A. Stewart, 2012. Have biopesticides come of age? Trends in Biotechnology, 30 (5): 250-258.

Grewal, P. S., 2000. Enhanced ambient storage stability of an entomopathogenic nematode through anhydrobiosis. Pest Management Science, 56 (5): 401-406.

Hirao, A., R. Ehlers \& O. Strauch, 2010. Life cycle and population development of the entomopathogenic nematodes Steinernema carpocapsae and S. feltiae (Nematoda, Rhabditida) in monoxenic liquid culture. Nematology, 12 (2): 201-210.

James, M., A. P. Malan \& P. Addison, 2018. Surveying and screening South African entomopathogenic nematodes for the control of the Mediterranean fruit fly, Ceratitis capitata (Wiedemann). Crop Protection, 105: 41-48.

Johnigk, S., S. Hollmer, O. Strauch, U. Wyss \& R. Ehlers, 2002. Heritability of the liquid culture mass production potential of the entomopathogenic nematode Heterorhabditis bacteriophora. Biocontrol Science and Technology, 12 (2): 267-276.

Kagimu, N. \& A. P. Malan, 2019. Formulation of South African entomopathogenic nematodes using alginate beads and diatomaceous earth. BioControl, 64 (4): 413-422.

Kaya, H. K. \& R. Gaugler 1993. Entomopathogenic nematodes. Annual Review of Entomology, 38 (125): $181-206$.

Kongu, Y. \& I. A. Susurluk, 2014. Comparison of virulence of hybridized entomopathogenic nematode Heterorhabditis bacteriophora (Rhabditida: Heterorhabditidae) strains and their parents. Turkish Journal of Entomology, 38 (2): 125-134.

Lacey, L. A. \& R. Georgis, 2012. Entomopathogenic nematodes for control of insect pests above and below ground with comments on commercial production. Journal of Nematology, 44 (2): 218-225.

Malan, A. P. \& S. D. Moore, 2016. Evaluation of local entomopathogenic nematodes for the control of false codling moth, Thaumatotibia leucotreta (Meyrick, 1913), in a citrus orchard in South Africa. African Entomology, 24 (2): 489-501.

Mokrini, F., S. E. Laasli, Y. Benseddik, A.B. Joutei, A. Blenzar, H. Lakhal, M. Sbaghi, M. Imren, G. Özer, T. Paulitz, R. Lahlali, \& A. A. Dababat 2020. Potential of Moroccan entomopathogenic nematodes for the control of the Mediterranean fruit fly Ceratitis capitata Wiedemann (Diptera: Tephritidae). Scientific Reports, 10 (1): 19204.

Mukuka, J., O. Strauch, C. Hoppe \& R. Ehlers, 2010. Improvement of heat and desiccation tolerance in Heterorhabditis bacteriophora through cross-breeding of tolerant strains and successive genetic selection. BioControl, 55 (4): 511-521.

Nimkingrat, P., S. Khanam, O. Strauch \& R. Ehlers, 2013a. Hybridisation and selective breeding for improvement of low temperature activity of the entomopathogenic nematode Steinernema feltiae. BioControl, 58 (3): $417-426$.

Nimkingrat, P., O. Strauch \& R. Ehlers, 2013b. Hybridisation and genetic selection for improving desiccation tolerance of the entomopathogenic nematode Steinernema feltiae. Biocontrol Science and Technology, 23 (3): $348-361$.

Perry, R. N., R. Ehlers \& I. Glazer, 2012. A realistic appraisal of methods to enhance desiccation tolerance of entomopathogenic nematodes. Journal of Nematology, 44 (2): 185-190.

Ramakuwela, T., J. Hatting, M. D. Laing, S. Hazir \& N. Thiebaut, 2016. In vitro solid-state production of Steinernema innovationi with cost analysis. Biocontrol Science and Technology, 26 (6): 792-808. 
Sabino, P. H. S., A. S. Negrisoli, V. Andaló, C. C. Filgueiras, A. Moino \& F. S. Sales, 2019. Combined application of entomopathogenic nematodes and insecticides in the control of leaf-miner Tuta absoluta (Meyrick) (Lepidoptera: Gelechiidae) on Tomato. Neotropical Entomology, 48 (2): 314-322.

Sajnaga, E. \& W. Kazimierczak, 2020. Evolution and taxonomy of nematode-associated entomopathogenic bacteria of the genera Xenorhabdus and Photorhabdus: an overview. Symbiosis, 80 (1): 1-13.

Salame, L., I. Glazer, M. T. Chubinishvilli \& T. Chkhubianishvili, 2010. Genetic improvement of the desiccation tolerance and host-seeking ability of the entomopathogenic nematode Steinernema feltiae. Phytoparasitica, 38 (4): $359-$ 368.

Santhi, V. S., D. Ment, L. Salame, V. Soroker \& I. Glazer, 2016. Genetic improvement of host-seeking ability in the entomopathogenic nematodes Steinernema carpocapsae and Heterorhabditis bacteriophora toward the Red Palm Weevil Rhynchophorus ferrugineus. Biological Control, 100 (1): 29-36.

Shapiro-Ilan, D., I. Glazer \& D. Segal, 1997. Genetic improvement of heat tolerance in Heterorhabditis bacteriophora through hybridization. Biological Control, 8 (2): 153-159.

Shapiro-llan, D. I., R. Han \& C. Dolinksi, 2012. Entomopathogenic nematode production and application technology. Journal of Nematology, 44 (2): 206-217.

Susurluk, A., I. Dix, E. Stackebrandt, O. Strauch, U. Wyss \& R. U. Ehlers, 2001. Identification and ecological characterisation of three entomopathogenic nematode-bacterium complexes from Turkey. Nematology, 3 (8): 833-841.

Susurluk, I. A., T. C. Ulu \& Y. Kongu, 2013. Tolerances of hybridized entomopathogenic nematode Heterorhabditis bacteriophora (Rhabditida: Heterorhabditidae) strains to heat and desiccation. Turkish Journal of Entomology, 37 (2): 221-228.

Ulu, T. C. \& A. Susurluk, 2018. Effects of several ingredients on in vitro mass production of Heterorhabditis bacteriophora HBH strain. Mediterranean Agricultural Sciences, 31 (3): 209-212.

Upadhyay, D. 2015. Lab-scale in vitro mass production of the entomopathogenic nematode Heterorhabditis bacteriophora using liquid culture fermentation technology. American Journal of Bioscience and Bioengineering, $3(6): 203-207$.

van Niekerk, S. \& A. P. Malan, 2014. Compatibility of biological control agents and agrochemicals to entomopathogenic nematodes, Steinernema yirgalemense and Heterorhabditis zealandica. African Entomology, 22 (1): 49-56.

van Zyl, C. \& A. Malan, 2014. Optimization of inoculation techniques for in vivo mass culture of entomopathogenic nematodes through nematode and insect host manipulation. African Entomology, 22 (2): 405-416.

Wright, D. J., A. Peters, S. Schroer \& J. Fife, 2005. "Application Technology, 91-106". In: Nematodes as Biocontrol Agents (Eds. P. S. Grewal, R. U. Ehlers \& D. I. Shapiro-Ilan), CABI, Wallingford, UK, 528 pp. 